Pak. j. sci. ind. res. Ser. B: biol. sci. 2021 64B(1) 1-6

\title{
Nutritional Assessment and Biological Activity of Moringa oleifera
}

\author{
Abdul Hameed Lanjwani*a , Allah Bux Ghanghroa, Taj Muhammad Jahangir Khuhawar ${ }^{b}$ \\ and Muhammad Farooque Lanjwani ${ }^{b}$ \\ ${ }^{a}$ Institute of Biochemistry, University of Sindh Jamshoro, Sindh, Pakistan \\ ${ }^{b}$ Institute for Advanced Research Studies in Chemical Sciences, University of Sindh, Jamshoro Sindh, Pakistan
}

(received October 15, 2018; revised March 11, 2019; accepted March 12, 2018)

\begin{abstract}
Moringa oleifera medicinal plant is used for medicinal purposes for the treatment of different types of human diseases. The fresh roots, stems, leaves, flowers and seeds have been selected for such medicinal purposes. The findings of present study indicated that an appreciable amount of proximate composition and phytochemical had been confirmed. The leaves and seeds for this study showed significant phytochemical sources including phenolic compound, flavonoid, tannin alkaloid and antioxidant content, whereas the most sensitive minerals composition sources including $\mathrm{Ca}, \mathrm{Fe}, \mathrm{Mg}, \mathrm{Na}, \mathrm{K}$, antibacterial activity including the Escherichia coli, Bacillus cereus and Staphylococcus aurous were found to be the most sensitive, while Klebsiella pneumonia least sensitive in this study. The growth of Escherichia coli is mostly inhibited by all plants components. Whereas, flowers and leaves showed good inhibition zone against Escherichia coli. The flowers of Maringa oleifera possessed antibacterial protein and peptide which showed highly significant against Staphylococcus aurous, Escherichia coli, Klebsiella pneumonia, Pseudomonas, proteus and enterobacter. The research will be supported for nutrition and sources of new drugs for the treatment of the different types of diseases.
\end{abstract}

Keywords: nutritional, antioxidant, antibacterial protein, medicinal plants

\section{Introduction}

Moringa oleifera Lam medicinal plant which belongs to Moringaceae family. It is distributed in the Himalayan foothills from north-eastern Pakistan to north-west Bengal, India, Afghanistan, Srilanka, South and West Asia and Africa. All parts of the plant were used for the treatment of various diseases forms. The root is used to treat different forms of diseases such as, fever, epilepsy, asthma, headache, gout, diarrhoea, hysteria, flatulence, scurvy, low back and kidney pain, flowers used for throat infections, hysteria and rheumatism as well as tonic abortion, seeds for tumour, ulcer, rheumatism and arthritis, and the leaves for bacterial infection, antioxidant, urinary tract infection and diarrhoea, HIV-AIDS, headache, hypertensive, lactating enhancer, fever, hepatic, ulcer, tumour, dysentery, catarrh and scurvy (Chaudhary and Chaurasia, 2017). The leaves of Moringa oleifera are also beneficial for the treatment of pneumonia, malaria, hyperglycaemia, diarrhoea, skin disease, flu, anticancer, heart burn antimicrobial, syphilis, dyslipidemia, scurvy, headache, antibiotic, anti-atherosclerotic, antidiabetic, neuroprotectant reduce cholesterol and blood pressure. The seeds for the treatment of chrohn's disease, gout,

*Author for correspondence;

E-mail: hameed.lanjwani@scholars.usindh.edu.pk hyperthyroidism, epilepsy, antiherpes simplex virus arthritis, sexually transmitted disease, cramp, antiinflammatory and antimicrobial agents studied by (Lakshmipriya et al., 2016). In the ancient world, Moringa oleifera was extremely valued. It is mentioned that leaves and fruits of Moringa in their diet to maintain healthy skin and mental alertness in the history dates back to 150 B.C. Moringa leaf extract was fed of the ancient Maurian soldiers of India in the warfront. Moringa is fabulous food tree with remarkable sources of nutrients including calcium, iron, vitamin $\mathrm{C}$ and vitamin A. It is described that the leaves of Moringa oleifera contain vitamin A ten times more than carrot, vitamin $\mathrm{C}$ seven times more than orange, seventeen times calcium than milk, iron 25 times more than spinach, potassium 15 more than banana and also contain vitamin B complex, magnesium, zinc, copper, manganese, chromium and phosphorus (Bhupendra and Chase, 2015). Antifungal, anti-inflammatory, antimicrobial, antifertility, anti-atherosclerotic, relieving pain, diuretic, regulating hypothyroidism, central nervous system depressant, asthma, hyperglycaemia, pneumonia, malaria, scurvy, diarrhoea dyslidemia, reduce blood pressure, reduce cholesterol, anticancer, antidiabetic, neuroprotection agent, skin disease, headache, bronchitis, eye and ear infection, heartburn, flu and syphilis have been cured by Moringa oleifera (Udikala et al., 2017; 
Rockwood et al., 2013; Mbikay, 2012). The all parts plant including roots, stems, leaves, flowers, fruits (Pod) and seeds are being used in the different types of diseases such as treatment of inflammation, hepatorenal disorders, infectious diseases, cardiovascular and gastrointestinal disorders studied by (Nath et al., 2015). The leaves of Moringa oleifera have possessed more vitamin A than carrots, and more potassium than bananas, more iron than spinach more calcium than milk, more vitamin $\mathrm{C}$ than oranges and protein quality equal to as milk and eggs (Sujatha and Patel, 2017).

\section{Materials and Methods}

Sample preparation. The fresh root, stem, leave, flower, seed that were being selected and collected from district Kamber, Sindh, Pakistan, had been dried under shade for about 15-30 days and ground. Further, powdered plants materials were made after dryness and stored in air tight bags for further analysis.

Estimation of phytochemical and biological activity methods. Proximate analysis. Total ash and moisture content were identified by oven/muffle furnace. Phytochemicals were screened studied by (Lanjwani et al., 2015). Carbohydrates by Anthrone method (Rawat et al., 2012), Protein by lowery method (Naidu et al., 2013).

Phytochemical analysis. Total phenolic contents were determined by Folin Ciocalteu method (Maurya and Singh, 2010), flavonoid by aluminium chloride method (Damodar et al., 2011), tannin by modified Prussian method (Sathishkumar and Baskar, 2015), total alkaloids by Dragendorff's method by (Sonal et al., 2011).

Minerals analysis. The plant samples were acid digested for mineral determination detected by (Lanjwani et al., 2016). Minerals were identified by atomic absorption spectrometry (Perkin Elmer AA 800).

Biological analysis. The content of antioxidant identified by iron reduction method (Patel et al., 2010), antimicrobial content by Agar-Well Diffusion Assay (Bonjar, 2014).

Antibacterial protein and peptide. Preparation of plant extracts, $10 \mathrm{~g}$ of plant powdered sample was taken and $100 \mathrm{~mL}$ of distilled water was added and kept on shaking water bath at room temperature for $24 \mathrm{~h}$ and then filtered through Whatman filter paper no 1 . Filtrate was treated with $20 \%$ trichloroacetic acid. Solution was stand at room temperature for one hour and centrifuged at $6000 \mathrm{rpm}$ for $15 \mathrm{~m}$. Precipitate is collected and solution was checked by $20 \%$ trichloroacetic acid for further precipitation. Precipitate was washed with acetone and dried. Precipitate was fully dissolved in distilled water than filtered was used for antibacterial protein $20 \mu \mathrm{L}$ every sample are used.

\section{Results and Discussion}

The results of present study showed that an appreciable amount of phytochemicals indicated that the aqueous extract is the best solvent for extraction including alkaloid, amino acids, phenolic compounds, tannins and flavonoids, whereas methanol extracts is the best solvent for saponins, proteins, carbohydrates, glycosides, terpenoids, steroids, fats and oils. The presence of phytochemicals has diversed medicinal properties including alkaloids for antimalarial, antispasmodic, analgesic and diuretic activity. Terpenoid for anticancer, antiviral, antibacterial, anthelmintic, antimalarial and anti-inflammatory and inhibition of cholesterol synthesis and also possess insecticidal activities. Saponin for antiviral, anti-inflammatory defense of plant and cholesterol reducing activity. Glycosides for antibacterial and antifungal properties. Phenols and flavonoid for antioxidant, antibacterial and antiallergic, etc. (Padalia and Chanda, 2015; Moteriya et al., 2015).

Proximate composition is shown in the Table 2, the high ash values obtained in this analysis, which is good sources of inorganic minerals. It is positive indication that high ash indicates high deposition of minerals it is good sign because ash is composed of minerals. Such variations may be occurred due to different areas of research which is impacted by various factors including climates geographical conditions. For tropical climates high moisture will be suitable in replacing loss of water from the body. The root of plants showed good sources of carbohydrate, whereas the highest $\%$ of protein was observed in the seeds. The building block of cell and body is protein. The leaves of Moringa oleifera have been used in eating in African countries including Ethiopia, Ghana, east Africa, Nigeria and Malawi. Moringa tree is also cultivated for foods, nutritional and medicinal purposes (Gomashe et al., 2014). The present result of protein and moisture were compared which was similar to reported (Yameogo et al., 2011; Manzoor et al., 2007). The protein and carbohydrate were investigated in the seeds, while similar finding reported by (Oliveira et al., 1999). The carbohydrates and ash contents in the leaves, flowers and seeds were 
Table 1. Phytochemical screening of the different parts of Moringa oleifera

\begin{tabular}{|c|c|c|c|c|c|c|c|c|c|c|}
\hline \multirow[t]{2}{*}{ Phytochemical } & \multicolumn{2}{|c|}{ Root } & \multicolumn{2}{|c|}{ Stem } & \multicolumn{2}{|c|}{ Leave } & \multicolumn{2}{|c|}{ Flower } & \multicolumn{2}{|c|}{ Seed } \\
\hline & $\overline{\mathrm{MET}}$ & $\overline{A Q}$ & $\overline{\mathrm{MET}}$ & $\mathrm{AQ}$ & $\overline{\mathrm{MET}}$ & $\mathrm{AQ}$ & $\overline{\mathrm{MET}}$ & $\mathrm{AQ}$ & $\overline{\mathrm{MET}}$ & $\mathrm{AQ}$ \\
\hline Alkaloids & - & - & - & - & + & - & - & - & - & ++ \\
\hline Phenolic compounds & + & +++ & +++ & +++ & + & +++ & + & +++ & + & +++ \\
\hline Tannins & +++ & +++ & +++ & +++ & + & +++ & +++ & +++ & + & +++ \\
\hline Flavonoids & - & ++ & - & - & + & - & - & ++ & ++ & + \\
\hline Saponins & ++ & + & + & + & + & + & ++ & ++ & +++ & +++ \\
\hline Amino Acids & +++ & +++ & - & +++ & - & +++ & - & +++ & +++ & +++ \\
\hline Protein & + & + & +++ & + & + & + & + & + & + & + \\
\hline Carbohydrates & +++ & + & +++ & + & + & +++ & ++ & +++ & +++ & +++ \\
\hline Glycosides & + & + & + & - & - & +++ & + & - & + & - \\
\hline $\begin{array}{l}\text { Steroids and } \\
\text { triterpenoids }\end{array}$ & +++ & ++ & +++ & - & +++ & +++ & +++ & +++ & +++ & + \\
\hline Fat and oils & + & + & + & + & + & + & ++ & + & +++ & + \\
\hline Vitamin C & - & - & - & & - & + & - & - & - & - \\
\hline
\end{tabular}

Note: $(+++)=$ Appreciable; $(++)=$ Moderate; $(+)=$ Trace amount; $(-)=$ absent; $($ MET $)=$ Methanol; $($ AQ $)=$ Aqueous.

Table 2. Proximate composition (\%) of Moringa oleifera

\begin{tabular}{lllll}
\hline \hline $\begin{array}{l}\text { Parts } \\
\text { of plants }\end{array}$ & Moisture & Ash & Carbohydrate & Protein \\
\hline Roots & 83 & 21 & 30.7 & 6.8 \\
Stems & 82 & 13.9 & 28.3 & 3.6 \\
Leaves & 77 & 20 & 28 & 10.1 \\
Flowers & 78.2 & 22 & 27.3 & 5.3 \\
Seeds & 24 & 20 & 19.8 & 36.7 \\
\hline \hline
\end{tabular}

being compared to the reported studies indicated in range (Sanchez-Machado et al., 2010).

Phytochemical and antioxidant content are shown in the Table 3. The leaves and seeds for this study showed appreciable sources of phytochemical including phenolic compounds, flavonoids, alkaloids and antioxidant content. This is investigated that phytochemical have adversed beneficial effects in the humans. For example, phenolic compounds and tannins, flavonoids having hypocholesterolemic, hypoglycaemic, anti-inflammatory, antioxidant, anticancer, antihypertensive properties (Oluwole et al., 2013). In the present result, the total

Table 3. Phytochemical and antioxidant content $(\mathrm{mg} / \mathrm{g})$ of Moringa oleifera

\begin{tabular}{llllll}
\hline \hline $\begin{array}{l}\text { Parts } \\
\text { of plants }\end{array}$ & $\begin{array}{l}\text { Phenolic } \\
\text { compound }\end{array}$ & Flavonoid & Tannin & Alkaloid & Antioxidant \\
\hline Roots & 112 & 20 & 64 & 0 & 62 \\
Stems & 221 & 51 & 65 & 0 & 18 \\
Leaves & 230 & 101 & 64 & 9.8 & 45 \\
Flowers & 153 & 37 & 65 & 0 & 55 \\
Seeds & 154 & 84 & 62 & 150 & 48 \\
\hline \hline
\end{tabular}

phenolic compounds, flavonoid and alkaloid were lower and tannin higher than reported by (Adeyemi et al., 2014).

Mineral composition is shown in the Table 4. It is observed that appreciable sources of principle essential macrominerals including $\mathrm{Ca}, \mathrm{Fe}, \mathrm{Mg}, \mathrm{Na}$, and $\mathrm{K}$. The leaves showed top nutritional values. The present results of $\mathrm{Ca}, \mathrm{Na}, \mathrm{Fe}$ and $\mathrm{Zn}$ were compared with previously reported including calcium and iron were investigated near about reported (Padalia and Chanda, 2015). The present results of $\mathrm{Mg}, \mathrm{Fe}$ are higher and $\mathrm{Ca}, \mathrm{Na}, \mathrm{K}$ and Mn lower than reported by (Aslam et al., 2005). Zn and $\mathrm{Ni}$ contents were investigated to be higher in degree, while $\mathrm{Cr}, \mathrm{Cd}$, Lead were lower than reported by (Limmatvapirat et al., 2013). The concentrations of

Table 4. Mineral composition $(\mathrm{mg} / \mathrm{Kg})$ of Moringa oleifera

\begin{tabular}{llllll}
\hline \hline Nutrients & Root & Stem & Leave & Flower & Seed \\
\hline Calcium & 2400 & 4000 & 16000 & 2000 & 1760 \\
Iron & 35.12 & 312.5 & 625.5 & 460.9 & 10.96 \\
Potassium & 1204.8 & 1212.8 & 1312.8 & 1101.6 & 1200 \\
Magnesium & 864.2 & 903.1 & 562.9 & 679.6 & 650.5 \\
Sodium & 1768 & 1136 & 1680 & 1300 & 1600 \\
Zinc & 2.2 & 15.2 & 17.6 & 14.6 & 26 \\
Manganese & 45.04 & BDL & BDL & BDL & BDL \\
Cobalt & BDL & 25.7 & BDL & BDL & BDL \\
Lead & 0.6 & 5.7 & 10.8 & 15.2 & BDL \\
Copper & BDL & BDL & BDL & 19.1 & 4.8 \\
Chromium & BDL & BDL & BDL & 0.8 & BDL \\
Nickel & 1.7 & 2.7 & 3.1 & 1.5 & 2.8 \\
Cadmium & BDL & BDL & BDL & BDL & BDL \\
\hline \hline
\end{tabular}

Note: (BDL) Below Detection Limit. 
cadmium have been indicated below detection limit which is toxic highly even at concentration low. Amount of concentration of lead and cobalt were recorded around permissible limit in the all parts. It is great advantage to be the consumers because of lead is highly toxic. Moringa is fabulous food tree with remarkable sources of nutrients including calcium, iron, vitamin $\mathrm{C}$ and vitamin A. It is described that leaves of Moringa oleifera contain vitamin A ten times more than carrot, vitamin $\mathrm{C}$ is seven times more than orange and seventeen times of calcium than milk, iron 25 times more than spinach, potassium 15 more than banana and also contain vitamin B complex, magnesium, zinc, copper, manganese, chromium and phosphorus (Bhupendra and Chase, 2015). Calcium is required for maintaining and formation of bone and teeth, blood clotting and muscle contraction, while potassium is most essential for regulation of water and electrolyte balance, nerve action, muscle function, acid balance in the body. Potassium cause muscle paralysis (Okiki et al., 2015).

Antibacterial activity results are summarized in the Fig. 1. Antibacterial activity including the Escherichia coli, Bacillus cereus and Staphylococcus aurous were found to be the most sensitive, while Klebsiella pneumonia least sensitive in the present study. The growth of Escherichia coli is inhibited by the mostly all parts of plants, whereas flowers and leaves showed good

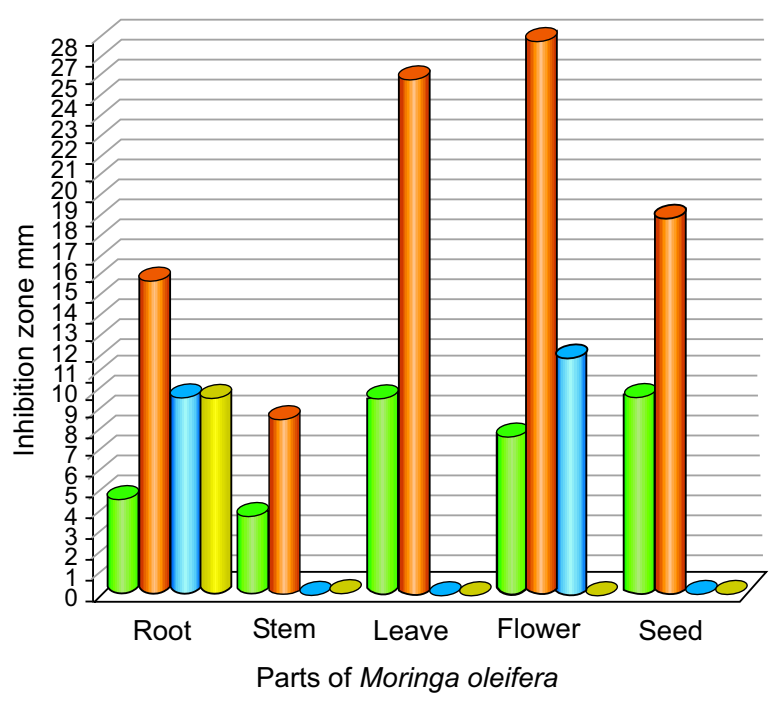

Bacillus cereous $\square$ Escherichia coli $\square$ Staphylococus aurous Klebsiella pneumonia

Fig. 1. Antibacterial analysis of methanol extract of Moringa oleifera. inhibition zone against Escherichia coli. It is highly active against Escherichia coli and Bacillus cereus which may be possessed important beneficial chemical including proteins, phenolic compounds, terpenoids, flavonoids and glycosides. $26 \mathrm{~mm}$ inhibition zone was measured by the leaves against Escherichia coli that were investigated, while similar in finding $23 \mathrm{~mm}$ inhibition zone was reported in (Abalaka et al., 2012).

Antibacterial proteins and peptides results have been showed in the Table 5. The flower of Maringa oleifera was possessed antibacterial proteins and peptides which showed highly significant against Staphylococcus aurous, Escherichia coli, Klebsiella pneumonia, Pseudomonas, Proteus and Enterobacter. It has been investigated that the flowers can be used to discovered new natural products in the forms of antimicrobial proteins and peptides. Among them proteins and peptides were recently observed as antimicrobial activities. The proteins and peptides are identified as important components of the innate defense system of fungi, bacteria, insects, plants and animals. Most of these defence proteins have multi tasked activities. The several peptides have capabilities to inhibit gram negative and positive bacteria were reported (Reddy et al., 2004).

Table 5. Antibacterial protein and peptide from flowers of Moringa oleifera

\begin{tabular}{ll}
\hline \hline Bacteria & $\begin{array}{l}\text { Diameter of zone of } \\
\text { inhibition mm }\end{array}$ \\
\hline Staphylococcus aurous & 15 \\
Pseudomonas & 14 \\
Escherichia coli & 8 \\
Klebsiella pneumonia & 6 \\
Proteus & 5 \\
Enterobacter & 4 \\
\hline \hline
\end{tabular}

\section{Conclusion}

Moringa oleifera provides huge nutrition including proteins, carbohydrates and principle essential macrominerals supplements which are beneficial for the treatment and prevention of many human being diseases. There is need to introduce such types of medicinal plants, which may play huge role in new medicinal drugs in reducing hunger, malnutrition and poverty from malnourished areas of Pakistan.

Conflict of Interest. The authors declare no conflict of interest. 


\section{References}

Abalaka, M.E., Daniyan, S.Y., Oyeleke, S.B., Adeyemo, S.O. 2012. The antibacterial evaluation of Moringa oleifera leaf extracts on selected bacterial pathogens. Journal of Microbiology Research, 2: 1-4.

Adeyemi, S.B., Ogundele, K.O., Animasaun, M.A. 2014. Influence of drying methods on the proximate and phytochemical composition of Moringa oleifera Lam. Global Journal of Medicinal Plants Research, 2: 1-5.

Aslam, M., Anwar, F., Nadeem, R., Rashid, U., Kazi, T.G., Nadeem, M. 2005. Mineral composition of Moringa oleifera leaves and pods from different regions of Punjab, Pakistan. Asian Journal of Plant Sciences, 4: 417-421.

Bhupendra, K., Chase, N. 2015. Moringa oleifera Lam. Panacea to several maladies. Journal of Chemical and Pharmaceutical Research, 7: 687-707.

Bonjar, G.S. 2014. Evaluation of antibacterial properties of Iranian medicinal-plants against Micrococcus luteus, Serratia marcescens, Klebsiella pneumoniae and Bordetella bronchoseptica. Asian Journal of Plant Sciences, 3: 82-86.

Chaudhary, K., Chaurasia, S. 2017. Neutraceutical properties of Moringa oleifera: a review. European Journal of Pharmaceutical and Medical Research, 4: 646-655.

Damodar, K., Bhogineni, S., Ramanjaneyulu, B. 2011. Phytochemical screening, quantitative estimation of total phenolic, flavanoids and antimicrobial valuation of Trachyspermum ammi. Journal of Atoms and Molecules, 1: 1.

Gomashe, A.V., Gulhane, P.A., Junghare, M.P., Dhakate, N.A. 2014. Antimicrobial activity of Indian medicinal plants: Moringa oleifera and Saraca indica. International Journal of Current Microbiology and Applied Sciences, 3: 161-169.

Lakshmipriya, G., Kruthi, D., Devarai, S.K. 2016. Moringa oleifera: a review on nutritive importance and its medicinal application. Food Science and Human Wellness, 5: 49-56.

Lanjwani, A.H., Ghanghro, I.H., Ghanghro, A.B., Khuhawar, T.M.J., Channa, M.J. 2015. Qualitative examination of phytochemicals from some indigenous medicinal plants. Sindh University Research Journal-SURJ (Science Series), 47: 261264.

Lanjwani, A.H., Ghanghro, A.B., Memon, F.M., Memon, M.N., Ghanghro, I.H., Channa, M.J. 2016. Extraction of trace minerals from some important medicinal plants growing in District of Kamber/ Shahdadkot, Sindh, Pakistan. Rawal Medical Journal, 41: 36.

Limmatvapirat, C., Limmatvapirat, S., Charoenteeraboon, J., Phaechamud, T. 2013. Inductively coupled plasma mass spectrometric determination of heavy metals in Moringa oleifera Lam. leaves. Research Journal of Pharmaceutical, Biological and Chemical Sciences, 4: 161-168.

Manzoor, M., Anwar, F., Iqbal, T., Bhanger, M.I. 2007. Physico-chemical characterization of Moringa concanensis seeds and seed oil. Journal of the American Oil Chemists' Society, 84: 413-419.

Maurya, S., Singh, D. 2010. Quantitative analysis of total phenolic content in Adhatoda vasica Nees extracts. International Journal of Pharm Tech Research, 2: 2403-2406.

Mbikay, M. 2012. Therapeutic potential of Moringa oleifera leaves in chronic hyperglycaemia and dyslipidemia: a review. Frontiers in Pharmacology, 3: 47 .

Moteriya, P., Satasiya, R., Chanda, S. 2015. Screening of phytochemical constituents in some ornamental flowers of Saurashtra region. Journal of Pharmacognosy and Phytochemistry, 3: 112-120.

Naidu, M.P., Rao, R.N., Chandra, B., Ravindra, A., Vinusha, B., Uday, K. 2013. Isolation and Purification of isoenzymes of Aspartokinase. BioMedical Engineering Online, 1: 3-7.

Nath, I., Paul, S., Nath, B. 2015. Moringa oleifera: bioinspired approaches to plant based nanomedicine, a mini review. European Journal of Molecular Biology and Biochemistry, 2: 186-189.

Okiki, P.A., Osibote, I.A., Balogun, O., Oyinloye, B.E., Idris, O. 2015. Evaluation of proximate, minerals, vitamins and phytochemical composition of Moringa oleifera Lam. cultivated in Ado Ekiti, Nigeria. Advance Biological Research, 9: 436443.

Oliveira, J.T.A., Silveira, S.B., Vasconcelos, I.M., Cavada, B.S., Moreira, R.A. 1999. Compositional and nutritional attributes of seeds from the multiple purpose tree Moringa oleifera Lamarck. Journal of the Science of Food and Agriculture, 79: 81.

Oluwole, S.I., Oluwole, A.A., Oluwaseun A. 2013. Comparative study on nutrient composition, phytochemical and functional characteristics of raw, germinated and fermented Moringa oleifera seed flour. Food Science and Nutrition, 1: 452463. 
Padalia, H., Chanda, S. 2015. Comparative phytochemical analysis of aerial parts of A. procumbeans, $F$. dichotoma, S. sponteneum, S. nigra and $T$. angustifolia. Journal of Pharmacognosy and Phytochemistry, 4: 11-16.

Patel, A., Patel, A., Patel, N.M. 2010. Estimation of flavonoid, polyphenolic content and in-vitro antioxidant capacity of leaves of Tephrosia purpurea Linn. (Leguminosae). International Journal of Pharma Sciences and Research, 1: 66-77.

Rawat, A., Mohsin, M., Sah, A.M., Negi, P.S., Singh S. 2012. Biochemical estimation of wildly collected Ganoderma lucidum from Central Himalayan Hills of India. Advances in Applied Science Research, 3: 3708-3713.

Reddy, K.V.R., Yedery, R.D., Aranha, C. 2004. Antimicrobial peptides: premises and promises. International Journal of Antimicrobial Agents, 24: 536-547.

Rockwood, J.L., Anderson, B.G., Casamatta, D.A. 2013. Potential uses of Moringa oleifera and an examination of antibiotic efficacy conferred by $M$. oleifera seed and leaf extracts using crude extraction techniques available to underserved indigenous population. International Journal of Phytotherapy Research, 3: 61-71.

Sánchez-Machado, D.I., Núñez-Gastélum, J.A., ReyesMoreno, C., Ramírez-Wong, B., López-Cervantes,
J. 2010. Nutritional quality of edible parts of Moringa oleifera. Food Analytical Methods, 3: 180.

Sathishkumar, T., Baskar, R. 2015. Screening and quantification of phytochemicals in the leaves and flowers of Tabernaemontana heyneana Wall.-A near threatened medicinal plant. Indian Journal of Natural Products and Resources (IJNPR) [Formerly Natural Product Radiance (NPR)], 5: 237-243.

Sonal, P., Nayana, K., Bakula, S., Mamta, S. 2011. Botanical identification and physico-chemical investigation of leaf of Nili-Nirgundi (Justicia gendarussa). International Journal of Pharmaceutical Sciences Review and Research, 10: 116121.

Sujatha, B.K., Patel, P. 2017. Moringa oleifera-Nature's Gold. Imperial Journal of Interdisciplinary Research, 3: 1077-1086.

Udikala, M., Verma, Y., Sushma, S.L. 2017. Phytonutrient and pharmacological significance of Moringa oleifera. International Journal of LifeSciences Scientific Research, 3: 1387-1391.

Yaméogo, C.W., Bengaly, M.D., Savadogo, A., Nikiema, P.A., Traore, S.A. 2011. Determination of chemical composition and nutritional values of Moringa oleifera leaves. Pakistan Journal of Nutrition, 10: 264-268. 